\author{
Нестерова И.В. ${ }^{1}$, Халтурина Е.О. ${ }^{2}$ \\ ${ }^{1}$ ФГАОУ ВО «Российский университет дружбы народов», Москва, Россия \\ ${ }^{2}$ ФГАОУ ВО «Первый московский медицинский университет имени И.М. Сеченова» Министерства \\ здравоохранения РФ (Сеченовский университет), Москва, Россия
}

Резюме. Неуклонный рост числа аутоиммунных заболеваний и иммуноопосредованных аутовоспалительных процессов вызывает повышенный интерес врачей всех специальностей к этой теме и делает крайне актуальным вопрос раннего выявления аутоиммунных расстройств/аутоиммунного синдрома (АС). Зачастую эти нарушения развиваются на фоне атипичного течения хронических активных вирусных инфекций, вызываемых персистирующими вирусами, в частности вирусами семейства Herpesviridae (АХА ГВИ) и остаются не диагностированными вследствие полисимптомности опосредуемых ими нарушений и различными «клиническим масками» вызываемых расстройств.

Разработанный нами полуколичественный метод скрининговой оценки содержания аутоантител в сыворотке крови пациентов, страдающих АХА ГВИ, вызываемой герпес-вирусами, с использованием метода ИФА (Immunodot), является высокоспецифичным, скрининговым методом, который может позволить проводить объективную оценку динамики течения аутоиммунного процесса, а также осуществлять контроль за эффективностью проводимой комплексной противовирусной и иммуномодулирующей терапии.

Детекция аутоантител различной специфичности в сыворотке крови пациентов, страдающих атипичной хронической активной инфекцией, вызываемой герпес-вирусами (АХАИ), является ранним диагностическим маркером, необходимым, в первую очередь, для выявления аутоиммунной патологии нервной системы, которая ассоциирована с длительным течением активного микст-герпесвирусного процесса.

Ключевые слова: герпесвирусы, аутоантитела, ганглиозиды, аутоиммунитет, иммунная дисфункция, пост-вирусный синдром хронической усталости

\author{
Адрес для переписки: \\ Халтурина Евгения Олеговна \\ ФГАОУ ВО «Первый московский медицинский \\ университет имени И.М. Сеченова» Министерства \\ здравоохранения РФ \\ 117452, Россия, Москва, ул. Моховая, 11, корп 10. \\ Тел.: 8(916) 650-15-14. \\ E-mail:jane_k@inbox.ru
}

\section{Образец цитирования:}

И.В. Нестерова, Е.О. Халтурина «Ранняя диагностика аутовоспалительных нарушений, ассоциированных с поствирусным синдромом хронической усталости и когнитивными расстройствами, при хронических микст герпес-вирусных инфекииях» // Медицинская иммунология, 2021. T. 23, № 4. С. 975-980. doi: 10.15789/1563-0625-EDO-2315

(C) Нестерова И.В., Халтурина Е.О., 2021

\author{
Address for correspondence: \\ Khalturina Eugenia $O$. \\ I. Sechenov First Moscow State Medical University \\ 117452, Russian Federation, Moscow, Mochovaya, 11, \\ bild. 10 . \\ Phone: 7 (916) 650-15-14. \\ E-mail:jane_k@inbox.ru
}

\section{For citation:}

I.V. Nesterova, E.O. Khalturina "Early diagnostics of autoinflammatory disorders associated with post-viral chronic fatigue syndrome and cognitive impairments in chronic mixed herpes viral infections", Medical Immunology (Russia)/Meditsinskaya Immunologiya, 2021, Vol. 23, no. 4, pp. $975-980$.

doi: $10.15789 / 1563-0625-E D O-2315$

DOI: $10.15789 / 1563-0625-E D O-2315$ 


\title{
EARLY DIAGNOSTICS OF AUTOINFLAMMATORY DISORDERS ASSOCIATED WITH POST-VIRAL CHRONIC FATIGUE SYNDROME AND COGNITIVE IMPAIRMENTS IN CHRONIC MIXED HERPES VIRAL INFECTIONS
}

\author{
Nesterova I.V. ${ }^{\text {a }}$ Khalturina E.O. ${ }^{b}$ \\ a Peoples' Friendship University of Russia, Moscow, Russian Federation \\ ${ }^{b}$ I. Sechenov First Moscow State Medical University (Sechenov University), Moscow, Russian Federation
}

\begin{abstract}
The steady increase in the number of autoimmune diseases and immune-mediated autoinflammatory processes causes an increased interest of doctors of all specialties in this topic and makes the issue of early detection of autoimmune disorders / autoimmune syndrome (AS) extremely urgent. These disorders often develop against the backdrop of an atypical stream of chronic active viral infections caused by persistent viruses, in particular those of the Herpesviridae family, and remain undiagnosed due to polysymptomatic disease, and various "clinical masks" of the disorders caused by them. The semi-quantitative method developed by us for screening assessment of the content of autoantibodies in the blood serum of patients suffering from ACAI caused by herpes viruses using the ELISA method (Immunodot) is a highly specific screening method that can allow for an objective assessment of the dynamics of the autoimmune process, as well as control the effectiveness of the ongoing complex antiviral and immunomodulatory therapy. The detection of autoantibodies of various specificity in the blood serum of patients suffering from an atypical chronic active infection caused by herpes viruses (ACAI) is an early diagnostic marker, necessary, first of all, to identify autoimmune pathology of the nervous system, which is associated with a long course of the active mixed herpes-viral process.
\end{abstract}

Keywords: herpesviruses, autoantibodies, gangliosides, autoimmunity, immune dysfunction, post-viral chronic fatigue syndrome

\section{Introduction}

The steady increase in the number of autoimmune diseases and immune-mediated auto-inflammatory processes provokes growing interest of doctors of all specialties in this topic and makes the issue of early detected autoimmune disorders/autoimmune syndrome (AS) extremely urgent $[2,9]$. These disorders often develop in parallel with aberrant input of chronic active viral infections caused by persistent viruses, particularly those of the Herpesviridae family, and remain undiagnosed due to polysymptomatic picture, as well as diverse related "clinical masks" [3, $4,7]$. It is shown, that viruses particularly the EpsteinBarr virus (EBV) is able to bind to B-lymphocyte receptors, participate in epigenetic regulation, DNA methylation in B lymphocytes that may be the basis for inducing autoantibody formation of different specificities, thereby promoting autoimmune process $[1,5]$. Besides, the phenomenon of crossreactivity between viral epitopes and human own protein epitopes has been described, which is both a trigger for various autoimmune disorders and a cornerstone that for formation of immunopathological disorders particularly mono- or polyvalent autoimmune processes with varying loci. Herpes-induced interferon system (IFN) suppressor develops altered response to viral invasion and contributes to a defect in system-induced IFN alpha and IFN gamma products in vitro, promoting long-term active replication of herpesviruses and pathological changes such as autoimmune disorders and various types of immunopathology [8].

Currently, there have been described 8 human herpesviruses (HHV) divided into 3 subfamilies: Alphaherpesvirinae, Betaherpesvirinae and Gammaherpesvirinae. All Herpesviridae viruses are characterized by pronounced tissue tropism, high mutability and a rapid transition from acute latent-to chronic infection with lifelong persistence in various human cells, including those of the monocyticmacrophage lineage and effector immune cells, thereby impairing immunobiological surveillance. Cases of co- and mixed infections caused by viruses of this family have been described at increasingly higher rate.

The effect on the immune system of any damaging factor, both exogenous and endogenous, including host damaged, infected or modified cells by viruses triggers activation of the immune system [10]. Moreover, it may be both local and systemic at the early stages with nonspecific character and manifested by produced pro-inflammatory factors, changes in microvasculature permeability and migration to the focus of damaged immune cells, primarily neutrophils - the main effectors of inflammation. 
Neutrophil degranulation in the focus of inflammation is accompanied by released proteolytic enzymes and reversed focus of damage. However, the ongoing activation of inflammatory factors leads to cell and tissue damage, release of autoantigens accompanied by produced of relevant autoantibodies and development of autoimmune reactions. The detection of autoantibodies of various specificities in patients with ACA HVI can be considered as an early novel preclinical marker of impaired autoimmune homeostasis and development of pathological processes as well as immune-mediated diseases and conditions [11].

In connection with the data noted above, an important and relevant aspect is the search for biological markers that objectively reflect features of the clinical state (clinical and biological correlations). The potential of using such indicators as predictors is also of great importance, allowing to reliably assess probability of positive or negative dynamics in developing disease even during the initial clinical examination.

The aim: our study is dedicated to determine markers of autoimmune disorders/autoimmune syndrome (AS) in patients suffering from mixed herpesvirus infections (HSVI) using a semi-quantitative method to screen for serum autoantibodies of various specificities in patients with ACA HVI.

\section{Materials and methods}

There were followed up 548 subjects, of both sexes, aged 25 to 68 years, suffering from atypical chronic active mono- and mixed HVI. Among them were selected 20 patients with mixed HVI suffering from severe disorders of the mnestic sphere, postviral syndrome of chronic fatigue and immune dysfunction, clinical signs of developing autoimmune syndrome - fibromyalgia, cephalgia, neuropathic pain and paresthesia, etc. comprising a study group.

The inclusion criteria were: clinical signs of the immunocompromised state characteristic of ACA HVI. Criteria for immunocompromised state are presented by repeated acute respiratory viral infections of bacterial-viral etiology with incidence rate up to 10-12 times a year, chronic recurrent herpes-viral infections (HSV1, HSV2), chronic CMV, EBV and HHV6 infections, chronic bacterial and fungal co-infections. The comparison group included 20 sex- and age-matched apparently healthy adults. The study was approved by the Ethics Commission, and informed consent was obtained from all patients for participation in the study, in accordance with the World Medical Association's Declaration of Helsinki (WMA Declaration of Helsinki - Ethical Principles for Medical Research Involving Human Subjects, 2013) and for the processing personal data. There was organized a single-centre, prospective, non- randomized study conducted at the "Clinical and Diagnostic center MEDSI Belorusskaya”, Moscow.

Along with routine methods (collection of anamnesis, methods of physical examination, $\mathrm{CBC}$, etc.), there were used serologic diagnostic methods to detect herpes virus infections (IgM VCA EBV, IgG VCA EBV, IgM CMV, IgG CMV IgM HSV1/2, IgG HSV1/2) by ELISA test systems NPO "Diagnostic Systems" (Russia).

The PCR method of the AmpliSens test system (Russia) was used to detect virus genome in biomaterial samples (blood, saliva, urine, scraping from the tonsils and the posterior pharyngeal wall). Methods of flow cytometry, ELISA were used to assess parameters of antiviral immunity (immunogram, INF-status, etc.). To detect autoantibodies in the blood serum, the ELISA (Immunodot-point solid-phase ELISA), Medipan GMBH, Germany, was used: AntiPhospholipid 10 Dot detecting $\operatorname{IgM} / \mathrm{G}$ antibodies against phospholipids and $\beta 2$-glycoprotein; ANA 12 Line Dot for detecting IgG antibodies to nuclear and cytoplasmic antigens; Anti-Gangliosid Dot specific to antiganglioside antibodies against a wide range of gangliosides (GM1-4; GD1a, b; GD2,3; GT1a, b; GQ1b; sulfatides). Based on the use of Immunodot technology, we have developed and implemented a semi-quantitative method for screening the level of serum autoantibodies of various specificities in patients suffering from herpes virus-caused ACAI.

Statistical analysis was performed by using the Microsoft Excel 2010 software package.

\section{Results and discussion}

Among the 548 examined patients, $36.6 \%$ of patients suffer from monoherpesvirus infections, of which $55.5 \%$ are patients with EBV infection; $35.3 \%$ - with HSV type 1 and $11.1 \%$ - with either HSV-2 and CMV, respectively.

$63.7 \%$ cases were presented with mixed herpesvirus infections.

The pattern of such mixed infections is dominated by combination of HSV1 + HSV2; EBV + HHV 6, $\mathrm{EBV}+\mathrm{CMV}+\mathrm{HHV6}$, as well as $\mathrm{EBV}+\mathrm{CMV}+$ HHV6 + HSV-1 - per $11.2 \%$ in each case. Further, the distribution of mixed infections by the occurrence of combinations is as follows: EBV + CMV (9.7\%); $\mathrm{EBV}+\mathrm{CMV}+\mathrm{HSV} 1(4.8 \%) ; \mathrm{EBV}+\mathrm{CMV}+\mathrm{HSV} 2$ $(3.2 \%)$.

According to our data, the patients in the study group were characterized by some symptom complex, including complaints of a prolonged sensation of severe weakness and chronic fatigue.

Patients were concerned with increased sweating, intermittent pain in the throat, muscles (transient myalgias) and joints (arthralgia), headache, longterm subfebrile fever, regional or extended lymphoadenopathy, sleep disorders (insomnia), loss of 
memory, attention, impaired intellect, with less often psychogenic depression. Moreover, in $100 \%$ of cases, this pathology was associated with chronic latent/ persistent HVI (HSV-1/HSV-2, EBV, CMV, HHV6). Most common dominant viruses in the mixed HVI were EBV and HHV6. Multiple symptoms and syndromes detected in $100 \%$ of patients with mixed ACA HVI pose great diagnostic difficulties for doctors of all specialties, which complicates timely diagnostics and administration of proper therapy.

We have shown that it is necessary to carry out PCR diagnostics aimed at detecting herpesviruses in various biomaterials: in saliva, in scraping from the tonsils, in scraping from the oropharynx to determine activity of the viral process. It is mandatory to quantify this viral load necessary to assess the dynamics of antiviral and immunotropic therapy.

The frequency of detected EBV genome in diverse samples from patients with ACA EBV infection (PCR) was as follows: $76.3 \%$ - saliva; $12.4 \%$ blood; $63.8 \%$ - scrapings from the back of the throat; $52.7 \%$ - tonsil scrapings; and $18.3 \%$ - urine.

However, up to the present time, the detection of the EBV genome in various biological environments of the body in such patients poses substantial obstacles for interpretation by doctors of other specialties, and often such patients remain neglected receiving no proper and timely therapy.

While studying the parameters of autoimmune homeostasis in patients with ACA HVI by using the innovative Immunodot technology, we developed criteria for the semi-quantitative assessment of the autoantibody level to a wide range of ganglioside antigens (GM1-4; GD1a, b; GD2,3; GT1a, b; GQ1b; sulfatides), phospholipids (cardiolipin, phosphatidic acids, phosphatidylcholine, phosphatidylethanolamine, phosphatidylinositol, phosphatidylserine, annexin $\mathrm{V}$, prothrombin, $\beta 2$-glycoprotein I), nuclear and cytoplasmic antigens (dsDNA, nucleosomes, Sm, ribosomes, RNP histones, SS-A $60 \mathrm{kD}$, SS-A 52 kD, SS-B, Scl-70, CENP-B, Jo-1). According to our data, the results of determining the level of autoantibodies were interpreted in accordance with the proposed reference range shown in arbitrary units (U) and interpreted as: negative result; low level; average level; high level; very high level. The magnitude of detectable antibody level shown in $U$ are presented for each Immunodot test (Table 1).

Patients of the study group were found to have serum autoantibodies of various specificity in 100\% of cases. Among them, they were dominated by antiganglioside antibodies IgM and IgG (AntiGangliosid Dot) found in the blood serum of $60 \%$ patients. Gangliosides are glycophospholipids containing a sialic acid residue found in the membrane of many cells, but their amount is specifically increased in neurons. They are necessary for cell growth and differentiation, transmission of nerve impulses, and mounting immune responses. Among them, autoantibodies to GM1 ganglioside are found in $80 \%$ of blood samples. Autoantibodies against the GM1 ganglioside initiate damage to the axolemma and also block voltage-gated calcium channels. It should be noted that often it is possible to identify a combination of various autoantibodies to gangliosides in the blood of patients with various clinical forms of the syndrome. The second place in the frequency of detected autoantibodies is held by antibodies to phospholipids and $\beta 2$-glycoprotein (Anti-Phospholipid 10 Dot), among which IgG to phosphatidylcholine predominates (45\%). $\beta 2$-glycoprotein $\mathrm{I}$ is a serum protein with natural anticoagulant activity. Circulating AFLA recognizes antigenic structures formed by the interaction of $\beta 2$-glycoprotein I and cardiolipin. Antibodies to cardiolipin and $\beta 2$-glycoprotein I are more often found in patients with the primary APS. IgG antibodies against nuclear and cytoplasmic antigens (ANA 12 Line Dot) were found in $16.7 \%$ of patients predominantly against dsDNA. Antinuclear antibodies (ANA) against extractable nuclear antigens consist of antibodies to soluble components of the cell nucleus (ribonucleoproteins). Normally, ANAs are undetected in vivo. However, during autoimmune pathology, the immune system starts to produce specific immunoglobulins to its own cells and related components. It is believed that immune complexes consisting of double-stranded DNA and specific antibodies (IgG and IgM) are involved in developing microvasculitis (Table 2).

It was shown that the largest amount of serum autoantibodies in examined patients was specific to a wide range of gangliosides. Among them, antibodies to GM1 ganglioside were determined - in 70\%; GM3 43\%; GD2.3-21.4\%; sulfatides - 32\%. Autoantibody levels varied in a wide range from low (30 U) to high (100 U) and correlated with the activity of the viral process and clinical symptoms.

Besides, our study allowed simultaneously identify autoantibodies to several types of autoantigens (antiganglioside and antiphospholipid) in several patients, which allows us to interpret emerging autoaggression as multivalent reaction. Hence, it opens up wide avenues for understanding etiopathogenetic mechanisms underlying comorbid conditions and syndromes in patients with ACA HVI.

Thus, the prevailing spectrum and a certain level of anti-ganglioside autoantibodies identified by us in patients suffering from ACAI caused by herpes viruses allow us to assess not only the activity of virus-induced autoaggression but also to dynamically monitor effectiveness of the ongoing complex antiviral and immunomodulatory therapy. 
TABLE 1. VALUES OF THE LEVEL OF DETECTABLE ANTIBODIES FOR EACH IMMUNODOT TEST

\begin{tabular}{|l|c|c|c|c|c|}
\hline \multicolumn{1}{|c|}{ Dot } & Negative result & Low level & Average level & High level & Very high level \\
\hline $\begin{array}{l}\text { Anti-Phospholipid } \\
10 \text { Dot }\end{array}$ & $<30 \mathrm{U}$ & $30-40 \mathrm{U}$ & $40-70 \mathrm{U}$ & $70-100 \mathrm{U}$ & $>100 \mathrm{U}$ \\
\hline Anti-Gangliosid Dot & $<20 \mathrm{U}$ & $20-40 \mathrm{U}$ & $40-70 \mathrm{U}$ & $70-100 \mathrm{U}$ & $>100 \mathrm{U}$ \\
\hline ANA 12 Line Dot & $<1.0 \mathrm{U}$ & $1-1.5 \mathrm{U}$ & $1.5-3.0 \mathrm{U}$ & $3.0-3.5 \mathrm{U}$ & $>5.0 \mathrm{P}$ \\
\hline
\end{tabular}

TABLE 2. DETECTION RATE OF THE SPECIFIC ANITBODIES

\begin{tabular}{|l|c|}
\multicolumn{1}{|c|}{ Antibody specificity } & Detection rate (\%) \\
\hline Antiganglioside antibodies IgM and IgG, among them: & $60.0 \%$ \\
\hline AutoAB to GM1 ganglioside & $80.0 \%$ \\
\hline $\begin{array}{l}\text { Antibodies to phospholipids and } \beta 2 \text {-glycoprotein, among } \\
\text { which: IgG to phosphatidylcholine }\end{array}$ & $45.0 \%$ \\
\hline IgG to nuclear and cytoplasmic antigens & $16.7 \%$ \\
\hline
\end{tabular}

\section{Conclusion}

In the present study, a predominant spectrum of autoantibodies of a certain specificity was revealed, an increase in various anti-ganglioside autoantibodies was demonstrated with adjusting their level in patients suffering from ACAI caused by herpes viruses and associated with a post-viral syndrome consisting of chronic fatigue, cognitive disorders, polyneuropathy, fibromyalgia. The data obtained indicate that the long-term course of active mono- and mixed HVI is associated with developing mono- or polyautoimmune syndrome, which can lead later to the manifested autoimmune diseases.
The semi-quantitative method developed by us for assessment of serum autoantibodies in patients with ACAI caused by herpes viruses by using ELISA (Immunodot) is a highly specific screening method that can allow to objectively assess dynamics of autoimmune process, as well as control effectiveness of the ongoing complex antiviral and immunomodulatory therapy.

The detection of serum autoantibodies of various specificity in patients suffering from atypical chronic active infection caused by herpes viruses (ACAI) is an early diagnostic marker, necessary, primarily to verify autoimmune pathology of the nervous system, which is associated with a long course of the active mixed herpes-viral process.

\section{References}

1. Bravender T. Epstein-Barr virus, cytomegalovirus, and infectious mononucleosis. Adolesc. Med. State Art Rev., 2010, Vol. 21, no. 2, pp. 251-264.

2. Ercolini A.M., Miller S.D. The role of infections in autoimmune disease. Clin. Exp. Immunol., 2009, Vol. 155, no. 1, pp. 1-15.

3. Fujinami R.S., von Herrath M.G., Christen U., Whitton J.L., von Herrath M.G. Molecular mimicry, bystander activation, or viral persistence: infections and autoimmune disease mechanisms of immunopathology that could lead to autoimmune disease. Society, 2006, Vol. 19, no. 1, pp. 80-94.

4. Hussein H.M., Rahal E.A. The role of viral infections in the development of autoimmune diseases. Crit. Rev. Microbiol., 2019, Vol. 45, no. 4. pp. 394-412. 
5. Kanduc D. The comparative biochemistry of viruses and humans: An evolutionary path towards autoimmunity. Biol. Chem., 2019, Vol. 400, no. 5, pp. 629-638.

6. Kutok J., Wang F. Spectrum of Epstein-Barr virus-associated diseases. Annu. Rev. Pathol., 2006, Vol. 1, pp. 375-404.

7. Levin L., Munger K., O’Reilly E., Falk K., Ascherio A. Primary infection with Epstein-Barr virus and risk of multiple sclerosis. Ann. Neurol., 2010, Vol. 67, pp. 824-830.

8. Rojas M., Restrepo-Jimenes P. Molecular mimicry and autoimmunity. J. Autoimmun., 2018, Vol. 95, pp. 100-123.

9. Serafini B., Rosicarelli B., Franciotto D. Dysregulated Epstein-Barr virus infection in the multiple sclerosis brain. J. Exp. Med., 2007, Vol. 204, no. 12, pp. 2899-2912.

10. Tracy S.I., Kalacheva K., Lunemann J.D., Luzuiaga K., Middeldorp J., Thorley-Lawson D.A. Persistence of Epstein-Barr virus in self-reactive memory B cells. J. Viorol., 2012, Vol. 88, no. 22, pp. 12330-12340.

11. Tuohy V.K., Kinkel R.P. Epitope spreading: A mechanism for progression of autoimmune disease. Arch. Immunol. Ther. Exp. (Warsz), 2000, Vol. 48, no. 5, pp. 347-351.

\section{Авторы:}

Нестерова И.В. - д.м.н., профессор кафедры аллергологии и иммунологии, факультет непрерывного медицинского образования ФГАОУ ВО «Российский университет дружбы народов», Москва, Россия

Халтурина Е.О. - к.м.н., доцент кафедры

микробиологии, вирусологии и иммунологии ФГАОУ ВО «Первый московский медицинский университет имени И.М. Сеченова» Министерства здравоохранения РФ (Сеченовский университет), Москва, Россия

\section{Authors:}

Nesterova I.V., PhD, MD (Medicine), Professor, Department of Allergology and Immunology, Faculty of Continuing Medical Education, Peoples' Friendship University of Russia, Moscow, Russian Federation

Khalturina E.O., PhD (Medicine), Associate Professor, Department of Microbiology, Virology and Immunology, I. Sechenov First Moscow State Medical University (Sechenov University), Moscow, Russian Federation
Поступила 22.03.2021

Отправлена на доработку 02.06.2021

Принята к печати 15.06.2021
Received 22.03.2021

Revision received 02.06.2021

Accepted 15.06.2021 